Journal of Nepal Geological Society, 2019, vol. 58 (Sp. Issue), pp. 13-19

DOI: https://doi.org/10.3126/jngs.v58i0.24569

\title{
Short Critical Note on Water Wealth of Nepal
}

\author{
Govinda Sharma Pokharel \\ Nagarjun Municipality 10, Kalanki, Kathmandu, Nepal \\ Email: govindaspokharel@gmail.com
}

\begin{abstract}
The message that Nepal is rich in water resources has been spread in Nepal since a long time. If one looks at the total quantum of water that flows out of Nepal in one year, the above message sounds valid but as the flow of water is not under anybody's control and flow occurs under gravity as it precipitates or exits the water springs, it should be considered in two dimensions: volume and time. In my opinion, Nepal is water stressed most of the time of year: flood stressed during the monsoon and drought stressed during the rest of the year.

Nepal is rich in ice-mass, which is depleting at an alarming rate due to global warming giving rise to formation and increase in volume of glacial lakes that increases the vulnerability and risks to the economic activities along the river basins. Similarly, Nepal is rich in groundwater resource with the total annual replenishable reserve of about $12 \mathrm{BCM}$ mostly located in the Terai plains. The most debatable is the surface water that mostly falls as rain during the monsoon and cascades down crossing into India, is often devastating, as it passes.

Nepal's water resource is generally related to its hydropower potential calculated as $83,000 \mathrm{MW}$ by Dr. Hari Man Shrestha back in the sixties. Hydropower potential is a number that is based on the energy potential and the market, therefore, it is changing from time to time due to change in demand pattern and the market rates.

Myopic view of looking at the Himalayan waters relating it to energy production as the energy production (TAF-June 2018) comprises a meager percentage of total benefit which lies mostly on multiple use of water directed towards the following two aspects: (1) Reduction in the losses of life and property due to floods and unwanted mountain phenomenon, mostly flood related disaster risk reduction, and (2) Flood Water management for converting the curse of floods into assets by way of its multiple uses, both consumptive as well as non-consumptive including food revolution, navigation, fishery, water supply, replenishment of ground water, energy production and recreation.
\end{abstract}

Keywords: Groundwater resource, Surface water, Terai Plain, Hydropower potential, Flood water management

\section{INTRODUCTION}

With an area of 147,480 sq. km, Nepal is ranked 93rd in the list of large countries by area; similarly, it is ranked 46th in the list of large countries by population. Therefore, Nepal cannot be called a small country. But, as it is located between two giants, it seems small. On the grounds of economy, wellness and happiness index, Nepal is located towards the bottom.

The message that Nepal is rich in water resources has been spread in Nepal since a long time. If one looks at the total quantum of water that flows out of Nepal in one year, the above message sounds valid but as the flow of water is not regulated and occurs under the action of natural forces as it precipitates or exits the water springs, it should be considered in two dimensions: volume and time. In my opinion, Nepal is water stressed most of the time of year: flood stressed during the monsoon and drought stressed during the rest of the year (Pokharel, 2018).

But, the statistics of annual average water content of Nepal shows that Nepal has about 225 BCM of surface water
(Sharma, 1983), over 12 BCM of annual recharge of ground water (Ministry of Energy, Water Resources and Irrigation) and $481.23 \mathrm{cu}$. km of ice in the third pole (Mool, et al., 2001) but the seasonal availability and the access are the main problems. Despite the large ice content in the Himalayan mountains, the contribution of ice to the river flow is a meager $9 \%$ and the figure of its annual recharge is hard to estimate. The total sum of all the water that is either located in Nepal or refurbished annually or passes the Nepalese territory into India is, therefore, calculated as $237 \mathrm{BCM}$. This figure is statistically 7,900 cum per capita, which is again calculated as 21,600 litres of water per capita per day.

The third pole located towards the north of Nepal occupies an area of about 22 percent of the total area of Nepal with the snow-covered peaks occupying an area of 5,323 sq. km and contains an estimated volume of $481 \mathrm{cu}$. km of ice (Mool, et al., 2001). This means, Nepal is rich in ice-mass, which is depleting at an alarming rate due to global warming giving rise to formation and increase in volume of glacial lakes that increases the vulnerability and risks to the economic activities along the river basins due to glacial lake outburst floods, commonly 
termed as GLOF. Similarly, Nepal is rich in groundwater resource with the total annual replenishable estimated reserve between 5.8 and 11.5 BCM mostly located in the Terai Plains. The most debatable is the surface water that mostly falls as rain during the monsoon and cascade down crossing into India, often devastating, as it passes by.

Nepal is drained by 6000 rivers and rivulets, which are generally characterized by their lengths, their origin in and outside Nepal and availability of water during the lean period.

Nepal's water resource is generally related to its hydropower potential calculated as $83,000 \mathrm{MW}$ by Dr. Hari Man Shrestha, who is the first man to predict $83,000 \mathrm{MW}$ hydropower potential in Nepal, back in the sixties (The Kathmandu Post, April 28, 2017). But, hydropower potential is a number that is based on the energy potential optimized based on the market, therefore, it is changing with time due to change in demand pattern, availability and the market indicators. The real benefits from the Himalayan waters related to flood water management, disaster mitigation, food production, navigation, etc. are generally omitted mainly due to ignorance of the facts and data.

The National River Linking Project of India formulated by Sir Arthur Cotton over 150 years ago considers flood water management in the Himalayas including Nepal for irrigating vast plains of India has never been publicly considered by the policy makers and planners in Nepal.

\section{PHYSIOGRAPHY}

Nepal is generally divided into six east-west elongated physiographic zones, which are sometimes divided into three zones as the Terai, the hills and the High Mountains. But, for the purpose of water wealth estimation and flood water management, it can be divided into the following four physiographic zones (Table 1).

The significance of this division is explained by the following points:

1) The High Himalaya zone is characterised by the fact that all the three major rivers cross this zone with many of their main tributaries fed by the Himalayan snow and ice melt. The main characteristic of these main rivers of Nepal, namely the Koshi, Gandaki and Karnali is that they are transboundary rivers which originate in china. Contribution of snowmelt is significant in the lean and pre-monsoon seasons. These three river systems drain most of Nepal.

2) Often, the Mahakali River is also included in the list of main rivers as it is the fourth largest river of Nepal but as it originates in the high mountains of Nepal and India and as it is a border river in most of its stretch, it is dealt with separately.

3) All the major spring fed and perennial rivers as the Mechi, Kankai, Kamala, Bagmati, West Rapti and Babai originate in the High Mountain as well as middle mountain regions. Large numbers of hydropower, irrigation and water supply projects are built in these rivers.

4) The third group of rivers originates in the Siwaliks, some of them are perennial but most of them flow only in the monsoon. Over 90 percent of the total rivers of Nepal fall under this category.

5) The fourth zone is the Terai, Nepal's rice field. It is characterized by deposition of sediments. About 20 BCM of total annual discharge of $237 \mathrm{BCM}$ originates in this zone and crosses the border into India.

\section{SOURCES OF WATER IN NEPAL}

Nepal is blessed with all four sources of water in all three states of it, but the main source is the surface water replenished by the monsoon rains annually with some addition in the non-monsoon months. The second important source is the ice melt in the third pole. The third very important source is the ground water mainly in the Terai plains but widespread in the mountains, where it is the main source of drinking water as well as the main source for spring-fed rivers that originate in the mountains. The contribution of the spring fed rivers to the flow of the first group of rivers is also significantly high. The fourth source of water is the air moisture cultivated widely throughout the mountains. Quantity-wise, the fourth source seems insignificant however its economic as well as livelihood importance is great.

Table 1: Physiographic zones of Nepal (after Mool et al., 2001)

\begin{tabular}{lcccc}
\hline \multicolumn{1}{c}{ Zone } & $\begin{array}{c}\text { Total Area, } \\
\text { sq. km. }\end{array}$ & With 3 zones & $\begin{array}{c}\text { Area in sq. km. for water } \\
\text { wealth estimation }\end{array}$ & $\begin{array}{c}\text { Percentage of } \\
\text { Total area of Nepal }\end{array}$ \\
\hline High Himalayas & 33,500 & 63,100 & 33,500 & 22.71 \\
High Mountains & 29,600 & & Mountains: 74,020 & 50.19 \\
$\begin{array}{l}\text { Middle Mountains } \\
\text { Siwaliks }\end{array}$ & 44,420 & 63,280 & 18,860 & 12.79 \\
Bhabhar (Nothern Terai) & 18,860 & & Terai: 21,100 & 14.31 \\
$\begin{array}{l}\text { Other Terai } \\
\text { Total }\end{array}$ & 21,100 & 21,100 & $147,481.00$ & 100.00 \\
\hline
\end{tabular}


Table 2: Summary of Glaciers and Glacial Lakes in the Nepal Himalayas (Mool et al., 2001)

\begin{tabular}{cccc}
\hline & $\begin{array}{c}\text { Total } \\
\text { Numbers }\end{array}$ & $\begin{array}{c}\text { Area, } \\
\text { sq. km. }\end{array}$ & $\begin{array}{c}\text { Ice Reserve, } \\
\text { cu. km }\end{array}$ \\
\hline Glaciers & 3,252 & $5,323.89$ & 481.23 \\
Glacial Lakes & 2,323 & 75.70 & - \\
\hline
\end{tabular}

\section{Ice Reserve of the third pole}

The study carried out by ICIMOD (Mool et al., 2001) shows that the total number of glaciers in the Nepal Himalaya is 3,252 and that their total ice reserve is 481.23 cubic $\mathrm{km}$. Similarly, the total area under glaciers is 5,323.89 sq. km, which is over $3.6 \%$ of the total area of Nepal.

The study of Himalayan glaciers shows that different types of glaciers contain varying quantity of ice with the valley glaciers containing up to $88 \%$ of the total quantity of ice reserve and the mountain glaciers as the distant second with the maximum ice reserve of up to about $46 \%$. Ice reserve in other types of glaciers is generally insignificant.

Accumulation of snow and ice over the top of the existing ice mass and ablation of ice at the lower levels is a continuous process. The rate of accumulation of snow and ice as well as the rate of ablation varies with season, altitude, slope aspect and many other parameters. But the most important from the point of view of Ice reserve is the total mass balance, which again varies from year to year. In the Nepal Himalayas, it is not practically possible to measure the annual change however a general trend can be observed from the study of long-term data. The mass balance study of the Himalayan glaciers located at elevations of about $5000-5400 \mathrm{~m}$ is found to be slightly negative with an average loss of about $15 \mathrm{~m}$ of ice reserve in 40 years between 1960 and 2000 (Lee, 2010), which is in general agreement with the impacts of global warming.

There has been general reduction in the area of glaciers in the Himalayas and the rate of their reduction is not the same in all the glaciers. It is observed in the Nepal Himalayas that the thickness of ice in a particular glacier is increased at higher elevations and ablated in lower elevations giving rise to formation as well as expansion of glacial lakes in favorable areas. Therefore, formation of new glacial lakes and increase in the area/volume of existing glacial lakes is the result of increased ablation of the glacier. The existence of a large number of glacial lakes in the Himalayas (Tables 2, 3 and 4) can be considered as proof of increased ablation.

There is a close linkage between ice reserve, glacial lake and temperature, which is more important from the point of view of global warming as temperature rise is inevitable. Therefore, risk of GLOF for all the activities along the course

Table 3: Basin-wise distribution of Glaciers and Glacial Lakes in Nepal (Mool et al., 2001)

\begin{tabular}{clcccccc}
\hline \multirow{2}{*}{ S. No. } & \multirow{2}{*}{ River Basin } & \multicolumn{3}{c}{ Glaciers } & & \multicolumn{2}{c}{ Glacial Lakes } \\
\cline { 3 - 4 } \cline { 7 - 8 } & & Numbers & Area, Sq. km & Ice Reserve Cu. Km nn & & Numbers & Area, Sq. km \\
\hline 1 & Koshi & 779 & $1,409.84$ & 152.06 & & 1,062 & 25.09 \\
2 & Gandaki & 1,025 & $2,030.25$ & 191.39 & & 338 & 12.50 \\
3 & Karnali & 1,361 & $1,740.47$ & 127.81 & & 907 & 37.67 \\
4 & Mahakali & 87 & 143.33 & 10.06 & & 16 & 0.38 \\
\hline
\end{tabular}

Table 4: Sub-basins (s/b) with largest number of Glaciers, Ice Reserves (Mool et al., 2001)

\begin{tabular}{clccccccc}
\hline & & & \multicolumn{3}{c}{ Glaciers } & & \multicolumn{2}{c}{ Glacial Lakes } \\
S. No. & River Basin/Sub- & Basin (s/b) & Numbers & Area, & Ice Reserve & & Numbers & Area, \\
& & & Sq. km & Cu. km & & & Sq. km \\
\hline A & Koshi Basin & 779 & $1,409.84$ & 152.06 & & 1,062 & 25.09 \\
1 & Tamor Sub-basin & 261 & 474.15 & 56.64 & & 356 & 7.32 \\
2 & Dudh Koshi s/b & 278 & 482.2 & 51.01 & & 473 & 13.07 \\
B & Gandaki Basin & 1,025 & $2,030.25$ & 191.39 & & 338 & 12.50 \\
1 & Budhi Gandaki s/b & 180 & 442.14 & 40.40 & & 37 & 0.64 \\
2 & Marsyangdi s/b & 311 & 614.31 & 54.99 & & 78 & 6.28 \\
3 & Kali Gandaki s/b & 399 & 562.67 & 51.65 & & 96 & 3.29 \\
C & Karnali Basin & 1,361 & $1,740.47$ & 127.81 & & 907 & 37.67 \\
1 & Bheri Sub-basin & 452 & 583.4 & 47.77 & & 152 & 9.16 \\
2 & Mugu Karnali s/b & 254 & 220.39 & 12.52 & & 280 & 8.56 \\
3 & Humla Karnali s/b & 424 & 534.53 & 36.00 & & 345 & 13.01 \\
D & Mahakali Basin & 87 & 143.33 & 10.06 & & 16 & 0.38 \\
\hline
\end{tabular}


of the first-order rivers and their tributaries is increasing within the limitations of topography, relief and geological condition.

As far as ice reserve of the third pole within Nepal is concerned, the figure of $481.23 \mathrm{cu}$. $\mathrm{km}$ of ice, which is about $430 \mathrm{BCM}$ of water in 1980 is replenished at an unknown rate and is depleting at an unknown rate due to ablation at lower altitudes has reduced by 29 percent to about 305 BCM (Bajracharya et al., 2014) requires a thorough research to accurately estimate the actual quantities of ice, mass balance, rate of ablation to be linked with risk of GLOF and water reserve in this vital source.

\section{Ground water}

The total volume of annually rechargeable ground water in Nepal is estimated between 5.8 and 11.5 BCM (Ministry of Energy, Water Resources and Irrigation, 2018). The ground water resource of Nepal is predominantly located in the plains of Terai is interlinked underground with the same in India and therefore is greatly affected by the over draw in the north Indian states of India as Bihar, Utter Pradesh and West Bengal; an alarming drawdown of ground water can be clearly seen in the satellite imagery of western UP and Punjab. The use of ground water in Nepal is dismal but due to the overuse across the border, the drawdown is disproportionally great. The total volume of ground water located in the hills and the mountains of Nepal is estimated at less than 2 BCM.

As the ground water table of the Terai is getting low and low every year with the amount of recharge much larger than the amount of ground water extracted, it is estimated that an average of 5 to $10 \mathrm{BCM}$ of ground water from the Nepalese territory is extracted in the neighboring states of India.

It is also noted by Ministry of Energy, WR and Irrigation, 2018 that a total of 4,434 sq. $\mathrm{km}$ of agricultural land is irrigated by ground water using mostly shallow tube-wells in the Terai. But it is silent about the total quantity of water used either individually or in totality.

In the mountains, water springs are the main source of drinking water, however, they feed most of the rivers both perennial and seasonal, and they are also used as source for many hill irrigation schemes under the farmer managed irrigation system. As the springs feed the rivers in the lean season, their importance as source of hydroelectricity and "cash box" for private developers has never been highlighted by the planners and other concerned authorities in the government.

As the spring water is considered as the best source for drinking water supply and other sources being considered stale, the importance of ground water cannot be overstressed. Spring sources are considered holy places in Nepal. Similarly, spiritual as well as environmental value of water springs can never be ignored.

\section{Surface Water}

Nepal is drained by 3 major river systems: the Sapta Koshi River System of the east, Sapta Gandaki River System of the middle and the Karnali River System of the west. All these river systems originate in Tibet, drain the northern face of the Himalayas, cross the great Himalayas and drain most of Nepal: the total basin area of these three rivers in Nepal is 98,547 sq. km measured at gauging stations located near their last lap in the mountains (Table 5). This figure corresponds to over 67 percent of the total area of Nepal which drain together almost 140 BCM annually at the gauging stations. The total drainage area of these rivers in China is about $40.5 \mathrm{sq} . \mathrm{km}$. These three major tributaries of the Ganga have a total annual flow of 208.26 BCM, which is almost half of the total flow of the Ganges (Sharma, 1983). The water contribution of these three rivers in dry season is almost $70 \%$ of the total flow of the Ganges at Farakka.

Other main rivers that originate in Nepal mountains and feed the Ganges either directly or by feeding the three major rivers are Mechi, Kankai, Kamala, Bagmati, West Rapti, Babai and Mahakali (Table 6). All these second order rivers are generally spring fed and have perennial flow. Despite their significant contribution both in monsoon and the leans seasons, these rivers are often referred to as marginalized rivers due mainly to much less attention given by the planners in the government both in Nepal and India though the real picture at the ground level revels that they are not at all marginalized and that their relative significance to the national economy is in proportion to the same for the first order rivers.

The third group of rivers of Nepal includes the ones that generally originate in the Siwalik range of mountains or their foothills in Bhabar or in Terai itself; most of these rivers remain practically dry in the non-monsoon season despite their majestic

Table 5: Major Rivers of Nepal (Dixit, 2008)

\begin{tabular}{lcccc}
\hline \multicolumn{1}{c}{ Total Basin Area, sq. km. } & $\begin{array}{c}\text { Koshi River at } \\
\text { Chatara }\end{array}$ & $\begin{array}{c}\text { Sapta Gandaki at } \\
\text { Narayanghat }\end{array}$ & $\begin{array}{c}\text { Karnali at } \\
\text { Chisapani }\end{array}$ & $\begin{array}{c}\text { Mahakali at } \\
\text { Pancheshwar }\end{array}$ \\
\hline Total & 60,400 & 34,960 & 43,679 & 15,260 \\
Within Nepal & 27,863 & 29,626 & 41,058 & 5,317 \\
$\begin{array}{l}\text { Annual Average Flow, } \\
\text { Cumecs* }\end{array}$ & 1638 & 1568 & 1337 & 600 \\
$\begin{array}{l}\text { Total Annual Discharge, } \\
\text { BCM* }\end{array}$ & 51.655 & 44.449 & 42.164 & 20.151 \\
\hline
\end{tabular}


Table 6: Second Order Rivers of Nepal (ICIMOD, 2001)

\begin{tabular}{lcccc}
\hline \multicolumn{1}{c}{ Name of River Basin } & $\begin{array}{c}\text { Basin Area, } \\
\text { sq. km }\end{array}$ & $\begin{array}{c}\text { Annual average } \\
\text { discharge, cumecs }\end{array}$ & $\begin{array}{c}\text { Total Annual } \\
\text { Discharge, BCM }\end{array}$ & $\begin{array}{c}\text { Minimum Lean } \\
\text { season Flow, cumecs }\end{array}$ \\
\hline Kankai at Mainachuli & 1148 & 60 & 1.89 & 9.0 \\
Kamala River & 1450 & 45 & 1.42 & 3.0 \\
Bagmati at Karmaiya & 2700 & 137 & 4.32 & 23.0 \\
West Rapti at Jal Kundi & 5150 & 123 & 3.88 & 15.0 \\
Babai at Bargad & 3000 & 87 & 2.74 & 11.0 \\
\hline
\end{tabular}

presence in the monsoon. These numerous drainage systems referred in Nepal as khahare are believed to contribute about $20 \mathrm{BCM}$ of water in the monsoon creating havoc with extreme bank cutting, flooding, inundation, siltation of the fields along their courses often causing great loss of life and property. Agriculture is the most adversely affected wealth by these rivers. Often, these rivers flow at the same level as the surrounding lands that urgently require channelization due to rapid rise in the riverbed caused by erosion in the Siwalik and the Bhabar areas.

It is estimated that an average of 205 BCM of annual surface runoff passes from Nepal to India through the main three rivers and the second category rivers combined together (Mool, et al., 2001). In addition to this, about 20 BCM of water passes through the border in the monsoon through seasonal rivers and streams originating either at the Siwalik or the foothills. On top of that, about 10 BCM of ground water from Nepal Terai is estimated to have been extracted in India without being noticed on the surface making the total volume of water crossing from Nepal to India as 235 BCM annually. Out of this annual total almost $85 \%$, i. e. about 194 BCM $(85 \%$ of 205 and all of 20) flows as the monsoon floods and the remaining $31 \mathrm{BCM}$ flows in the remaining 8 months or so (Sugden, 2014) with the $10 \mathrm{BCM}$ of ground water being extracted unnoticed from the surface. The flow of ground water is generally believed to be taking place in the non-monsoon season. It clearly shows the quantum of water stress in the monsoon due to excessively high floods followed by over eight months of lean flow dominated by water scarcity with practically dry riverbeds except in the first and second order rivers. The most noticeable fact from the frog's eye view is that the vicinity of the first order rivers are characterized by verticality induced drought.

The water stress of the monsoon can be illustrated from the facts that the recorded peak instantaneous flood in the Karnali River at Chisapani in 1975 monsoon was 19,890 cumecs (Gyawali, 2001) and its lean season flow is 214 cumecs. Similarly, the Sapta Koshi River had a peak instantaneous flood of about 25,000 cumecs in 1954 and 1968 at the gauging station at Chatara; the lean season minimum flow is recorded as 280 cumecs. The ratio of river discharge at peak instantaneous flood and the lean seasons for both Karnali and the Sapta Koshi show the water stress in the basins and that the stress increases along the river flow.

The main source of water in Nepal is the monsoon precipitation that lasts for about 70 days starting in the month of June and ending in mid-October with over 80 percent of annual precipitation occurring in this duration. Therefore, Nepal is always water stressed, which is totally against the general belief that Nepal is rich in water resources, which is often quoted as second to Brazil. Therefore, Nepal is water stressed: flood stressed in the monsoon and stress of water scarcity in the rest of the months.

GFDRR Report 2010 on the 2008 floods of Bihar from the embankment breach in the Koshi River narrates true picture of what happened in the floodplains of Bihar and what was the extent of loss of human as well as other lives and properties that was caused by a minor flood of 4,704 cumecs. The history of the Koshi River flood shows that the flood that breached the embankment in 2008 is a regular flood which was witnessed every year between 1948 and 1978. The peak flood figures of the Koshi River as recorded in Chatara gauging station located near the proposed high dam site are presented in Table 7. It is evident that there is a very high potential of much larger floods in the Koshi River compared to the one witnessed in 2008 as the recorded peak discharges are many times higher in most of the years. Floods in the Koshi River and breaching of embankments is a regular phenomenon in Bihar; There are about 8 to 10 incidents of such breaches of embankments of the main Koshi River channel mainly after the completion of the Koshi Barrage in 1963, though none of them received any such attention as the floods of 2008. The loss of life due to such events or any other event is invaluable and the loss of property due to such breaches can amount to tens of billions of USD.

Table 7: Peak flood frequency at Station no. 695 from 1948 to 1978 (31 years) (after GFDRR, 2010)

\begin{tabular}{clll}
\hline S. No. & \multicolumn{1}{c}{ Peak floods } & $\begin{array}{c}\text { Number } \\
\text { of } \\
\text { Years }\end{array}$ & Remarks \\
\hline 1 & $\begin{array}{l}\text { Peak floods larger than } \\
\text { the Aug 18, 2008 flood } \\
(4,704 \text { cumecs })\end{array}$ & $\begin{array}{l}31, \\
\text { every } \\
\text { year }\end{array}$ & \\
2 & $\begin{array}{l}\text { Peak flood of up to } \\
10,000 \text { cumecs }\end{array}$ & 12 & \\
3 & $\begin{array}{l}\text { Peak flood of up to } \\
\text { 20,000 cumecs }\end{array}$ & 2 & Aug 24, \\
4 & $\begin{array}{l}\text { Peak flood of 24,217 } \\
\text { cumecs }\end{array}$ & & $\begin{array}{l}1954 \\
\text { Peak flood of 25,853 } \\
\text { cumecs }\end{array}$ \\
\end{tabular}


Table 8: Multiple benefits of regulated water for the Sapta Koshi High Dam Project

\begin{tabular}{|c|c|c|c|c|c|c|}
\hline \multirow{2}{*}{ S. No. } & \multirow{2}{*}{ Benefit Type } & \multicolumn{2}{|c|}{ Benefit, \% } & \multirow{2}{*}{ Weightage, $\%$} & \multicolumn{2}{|c|}{ Total weighted benefit, $\%$} \\
\hline & & Nepal & India & & Nepal & India \\
\hline 1 & $\begin{array}{l}\text { Flood control \& flood plain } \\
\text { reclamation }\end{array}$ & 5 & 95 & 30 & 1.5 & 28.5 \\
\hline 2 & Land Improvement & 5 & 95 & 25 & 1.25 & 23.75 \\
\hline 3 & Electricity Generation & 100 & 0 & 12 & 12 & 0 \\
\hline 4 & Navigation & 80 & 20 & 10 & 8 & 2 \\
\hline 5 & Irrigation & 15 & 85 & 6 & 0.9 & 5.1 \\
\hline 6 & Tourism & 70 & 30 & 5 & 3.5 & 1.5 \\
\hline 7 & Fishery & 70 & 30 & 5 & 3.5 & 1.5 \\
\hline 8 & Ground water Recharge & 5 & 95 & 5 & 0.25 & 4.75 \\
\hline 9 & Water Supply & 70 & 30 & 2 & 1.4 & 0.6 \\
\hline Total & & & & & 32.3 & 67.7 \\
\hline
\end{tabular}

However, it is to be noted that the per capita water of Nepal is 21,462 cubic meter which is very high compared to many countries including the ones in the neighborhood. It means that the country has a better potential of converting the water into a resource that may generate wealth for the benefit of the people and more so in the context of more acute water stress across the border in India that has to sustain a population of over 400 million in the states of West Bengal, Bihar and UP alone.

\section{WATER WEALTH}

Cambridge English Dictionary defines Wealth as: 1. a large amount of money or valuable possessions that someone has: 2. a large amount of something good

The Oxford Thesaurus defines wealth as: amass wealth money, cash, capital, treasure, fortune, finance, property, riches, assets, possessions, resources, goods, funds.

Hence, my understanding of wealth is that it is the abundance of large amount of money or valuables with high purchasing capacity in the market or other assets that can be converted into money or valuables with high market value

As per the above definitions of wealth in English, the flood of water in the monsoon cannot be termed as wealth as its abundance causes disaster leading to loss of life and property. Similarly, the scarcity of water in the non-monsoon months cannot either be called a wealth as there is no abundance of it during the above-mentioned period.

It is obvious from above that Nepal has abundance of water in the monsoon. Our problem is that we have too much of it in monsoon and too little of it in the non-monsoon and therefore we need to add value to it to create a balance between the surplus of water in the monsoon and its scarcity in the lean period. This is how the curse can be converted into wealth

But, the over-abundance of water in the monsoon together with its scarcity in the non-monsoon months in Nepal and in north Ganga Plain with over 400 million people to feed has an obvious potential of converting it into an asset or wealth. But, the conversion maybe partial as it will be linked with demand and the market price defined together by to its feasibility and willingness to not only pay for it but also to accept the new political-economic equation in south Asia.

Therefore, the first step should be the study and research on the technical, market and environmental feasibility of flood water management with due attention to the ecosystem services. Due attention should also be given to the fact that the water bodies in question are not only economic entities that can be exploited indiscriminately to any lengthbut also important is to consider the fact that they are living entities on which our livelihoods, culture, tradition, civilization with emotional as well as spiritual values depend.

\section{Multiple Benefits of Regulated Water}

The water of Nepal is generally linked to the generation of electricity only as reservoir type projects with considerable flow regulation have been conceived as hydroelectric projects. This has led to making the energy generated from such projects overly expensive as all the costs that should have been shared by various end-users are loaded to the cost of electricity generation. The examples of such projects are the Kulekhani Hydroelectric Project, Budhi Gandaki Hydroelectric Project, West Seti Hydroelectric Project, etc.

The government of Nepal, by practice, has been traditionally focusing on three main aspects of water use, namely, electricity generation, irrigation and water supply. Water induced disasters is the late addition to it. This is evident from the fact that the government of Nepal has three departments under the ministry of water resources: department of electricity development, department of irrigation and department of water induced disasters. Inland Navigation started to appear on paper since 1997 but no serious homework has been done at any level in Nepal. This is evident from the recent news on media that there has been some kind of agreement between India and Nepal 
on using the Gandaki river for inland navigation without paying any attention to the fact that the river remains practically water scarce for all the year except in the monsoon as all the water is used in irrigation in India and that the quantity of water available for Nepal is so small that inland navigation by anything but a dugout boat seems impractical.

The multiple benefits from regulated water can be illustrated from Table 8, generated for the Koshi high dam project (Pokharel, 2018). The table shows that the weightage of electricity generation for the case of Sapta Koshi high dam project is as low as 12 percent and if all the costs are loaded to the activity having only 12 percent weightage, then the project on electricity generation may be economically unfeasible but if the costs are evenly distributed, the investment will be sound from economic perspective. In other storage projects, the weightage for the benefit types may be different but all such benefits can be obtained from flood water management in Nepal.

The most complicated is the political-economic importance of mega flood water management projects as they can have a strong political as well as economic leverage of the source partner on the other beneficiary partner. Therefore, this aspect of the project is closely linked to the willingness of the partners to go ahead with such projects and it seems to be the main reason for the delays in implementation of such projects in Nepaldespite their multisided advantage and attractive economic feasibility.

\section{CONCLUSIONS}

1. Nepal is a water stressed country with stress of oversupply in the monsoon and short supply rest of the year.

2. As the primary source of the Himalayan waters is the monsoon precipitation occurring in a short span of over 2 months, its conservation and management can only make Nepal rich in water resources.

3. Equating water resources of Nepal with electricity generation only is the myopic view, which should be widened considering the multiple benefits of regulated water with most of the benefits concentrated on life security, agro revolution for food security, navigation with access to the open sea as well as inland navigation, irrigation, replenishment of ground water reserve, etc.

4. The economic as well as social benefits of flood water management in Nepal is unquestionable however willingness to accept the new political-economic equation in south Asia should not continue to be the decisive factor to take such projects forward as such projects help achieve prosperity at the cost of conflicts responsible for poverty and backwardness in the otherwise most resourceful areas of south Asia.

\section{REFERENCES}

Bajracharya, S.R., Maharjan, S.B., Shrestha, F, Bajracharya, O.R., and Baidya, S., 2014, Glacier status in Nepal and decadal change from 1980 to 2010 based on landsat data. Kathmandu, ICIMOD, 88p.

Dixit, A., 2008, Dui Chhimekiko Jal Yatra "Water Tour of two Neighbors" Action Aid and Nepal Water Conservation Foundation, NWCF, 178p.

Sugden, F., Shrestha, L., Bharati, L., Gurung, P., Maharjan, L., Janmaat, J., Price, J.I., Sherpa,T.Y.C., Bhattarai, U., Koirala S., and Timilsina, B., 2014, Climate Change, Out-migration and Agrarian Stress: The Potential for Upscaling Smallscale Water Storage in Nepal, IWMI Research Report 159, 42p. https://doi.org/10.5337/2014.210

GFDRR, 2010, Bihar Koshi Flood, 2008, Needs Assessment Report prepared by Government of Bihar, World Bank, Global Facility for Disaster Reduction and Recovery (GFDRR), commonly known as GFDRR Report, 74p.

Gyawali, D. 2001, Rivers, Technology and Society, Learning the lessons of water management in Nepal, Himal Books and Panos South Asia with Nepal Water Conservation Society, paperback edition 2003, 281p.

Lee, A.R., 2010. The Glaciers of the Hindu Kush-Himalayan Region, A summary of the science regarding glacier melt/retreat in the Himalayan, Hindu Kush, Karakoram, Pamir, and Tien Shan mountain ranges (Technical paper), $16 \mathrm{p}$.

Mool, P.K., Wangda, D., Bajracharya, S.R., Kunzang, K., Gurung, D.R., and Joshi, S.P., 2001, Inventory of Glaciers and Glacial Lakes and Glacial lake Outburst Floods, Monitoring and Early Warning Systems in the HinduKush-Himalayan Region, ICIMOD, $363 \mathrm{p}$.

Pokharel, G.S., 2018, Nepal-Bharat Relations, Economic Development and Cooperation, edited by Tikaram Paudel and Deepak K Adhikari, Neeti Anusandhan Pratishthan Nepal, NeNAP, 2018, pp 107-110.

Sharma C.K, 1983, Water and Energy Resources of the Himalayan Block, Published by Mrs. Sangeeta Sharma, Bishalnagar, Kathmandu, 477p.

Shrestha, H.M., 1966, Ph. D. Thesis at Moskovskii Energetichheski Institut, USSR (unpublished).

The Kathmandu Post, 2017, April 28 . https://doi.org/10.1093/ejil/chx070 
